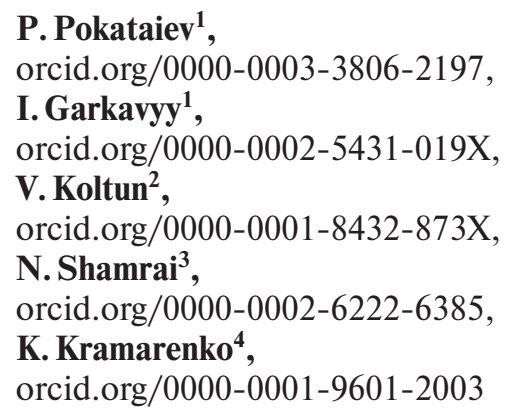

1 - Classical Private University, Zaporizhzhia, Ukraine, e-mail: victor30077788@gmail.com

2 - National Academy of Public Administration under the President of Ukraine, Kyiv, Ukraine

3 - Kyiv City State Administration, Kyiv, Ukraine

4 - National Academy of the National Guard of Ukraine, Kharkiv, Ukraine

\title{
STATE AND REGIONAL POLICY ON INDUSTRIAL WASTE MANAGEMENT: THE EU EXPERIENCE FOR UKRAINE
}

Purpose. To identify the main trends caused by the divergence of the policy of Ukraine and the EU in the formation and accumulation of waste and threats to the environment.

Methodology. Using the methods of content analysis, quantitative and qualitative comparison, EU policy on waste management is analyzed and logical generalization is used to establish the features of waste management financing for industries and regions.

Findings. Regional irregularities of industrial waste accumulation, including hazardous waste, trends of their change are revealed. The reasons for regional peculiarities of waste management in the EU and Ukraine are established. It is established that the distribution of capital investments both in environmental protection in general and in waste management in particular does not always coincide with the leading regions of accumulation. It is established that limitation of financial instruments for waste management only by budgetary resources leads to a reduction in capital investment. A comparison of trends in environmental spending and waste management indicated a significant difference. Analysis of environmental investment by polluting industries, which are unevenly represented in different regions, revealed a significant difference between them.

Originality. Regions that are the main polluters have been identified. The discrepancy between trends of capital investments in environmental protection and waste management was revealed. It is established that the list of leading regions in terms of capital investments in environmental protection does not correlate with the list of leading regions of waste accumulation. It is pointed out that uneven investment creates risks of increasing the rate of waste accumulation, in particular hazardous waste. Forecasting of indicators of waste management of the following periods is carried out.

Practical value. There are risks of increasing the rate of waste accumulation, especially hazardous waste, both in Ukraine in general and in some regions, inequalities in some areas in the amount of capital investment into environmental protection, which will form an effective waste management policy. Identifying common features and differences in waste management in the EU and Ukraine will allow implementing effective environmental protection tools, reducing risks in industrial waste management.

Keywords: industrial waste, state policy, settlements, regions

Introduction. According to the National Waste Management Strategy until 2030 (The Law of Ukraine, Document 697-VIII, 2019), there were 5,470 landfills for waste storage in Ukraine, of which, at the time of writing (2016) 305 were overfilled while 1,646 did not meet environmental standards. The vast majority of these facilities $(99 \%)$ do not meet EU requirements. The territory occupied by "stored" or "temporarily placed" industrial waste in Ukraine is more than 165 thousand hectares. This is more than $2.75 \%$ of the territory of Ukraine. The volume of waste of I-IV hazard class exceeds 37 billion tons. Unlike the European Union (Directive 2008/98/EC of the European Parliament and of the Council of 19 November 2008 on waste and repealing certain Directives) industrial waste is not sorted, so industrial waste that is taken to landfills contains resource and valuable components as well as dangerous and harmful ones [1].

This fact significantly complicates their use in the future as raw materials, on the one hand, and, on the other hand, complicates their handling during storage, because the protection of the environment from their impact is worth considerable effort and financial resources [2, 3]. A clear example of this is 32 tailing dumps with an amount of 162 million tons of industrial waste in the Dniester river basin, regular floods of these dumps pose a risk of dam failure and, consequently, pollution of the entire Dniester basin. These tailing dumps are on the balance of 12 commercial enterprises, i.e. the intervention of

(C) Pokataiev P., Garkavyy I., Koltun V., Shamrai N., Kramarenko K., 2021 local authorities is normatively and organizationally limited as well as the budgeting of environmental protection measures, which creates additional risks.

All indications are that industrial waste management is in poor condition and requires financial and organizational efforts not only in terms of national policy but also the local government of each of the settlements of Ukraine.

Literature review. The problem of national environmental policy and industrial waste management is widely discussed in the domestic scientific literature. One of the most thorough documents on these issues is the national report that combines and analyzes the views of the scientific community $[4,5]$. In particular, it is stated that the actual volumes of accumulated waste are much higher than those recorded in the statistical reporting (State Statistics Service of Ukraine, 2020), because the waste of non-operating enterprises is not taken into account.

Bilan, et al. [6], Voitsikhovska, et al. [7] analyzed the experience of EU countries in addressing issues of industrial waste management. Soroka [8] studied the state and directions of development of environmental policy of Ukraine and the participation of civil society in the development and implementation of this policy. Chukurna, et al. [9] formed a theoretical approach to the integrated development of production under the condition of waste disposal, paying attention to the institutional preconditions of this process and its investment.

These issues have also been studied by foreign scientists. In particular, Koithen [10] provides an overview of the national context related to the implementation of the Sustainable De- 
velopment Goals in Ukraine, considers the institutional system created by EU national parliaments to implement SDGs and provides recommendations on public policy for implementing environmental standards and budgeting environmental programs. Cabannes [11] considers how the formation of the state budget with the participation of local authorities contributes to the achievement of SDGs and provides specific recommendations using examples of innovative practices [11]. Ilić [12], Prieto-Sandoval [13], Geissdoerfer [14] considered the problems of waste management and budgeting of this process from the point of view of circular economy. These aspects are considered more thoroughly in the work of Reike [15]. The issue of system dynamics of waste management is considered by Ghisolfi [16, 17]. Bazaluk presented an analysis of modern methods of waste accumulation and use [18, 19].

Unsolved aspects of the problem. In the presented literature review, scientists have thoroughly studied various problematic aspects of industrial waste management. Unfortunately, the issues of the reasons for the formation of regional peculiarities of waste generation, its processing and placement in storage sites were left out of consideration. In this respect, the EU experience for Ukraine has not been critically interpreted.

The purpose of the article is to make a comparative analysis of industrial waste management policy in Ukraine and the EU, to identify and analyze the main trends due to differences in approaches to waste generation and accumulation policy and the existing environmental threats associated with waste management policy in Ukraine.

Methods. The study was performed using general and special methods of cognition. Using the methods of content analysis, quantitative and qualitative comparison, the main approaches of EU countries to waste management are analyzed, in particular, the features of funding programs and approaches to waste management. Methods of comparative analysis, logical generalization, quantitative and qualitative comparison are used to establish the features of trends in financing waste management, its formation, disposal and accumulation for industries, individual regions and settlements.

Results. Using the methods of content analysis, quantitative and qualitative comparison, the main approaches of EU countries to waste management are analyzed, in particular, the features of EU funding of programs and approaches to waste management. Analysis of waste generation in European countries indicates a significant unevenness of its production in different countries. All these countries comply with the norms and rules of waste generation and recycling approved by the European Parliament. But the level of waste generation (and, accordingly, the level of processing) in different regions varies in the specific value per capita by $\sim 25$ times. The list of leaders in waste generation is taken mainly by countries whose economy and social system were close to the USSR. The reason for this is not only the backlog of technology, but also non-compliance with the European principle of waste minimization. That is, regional differences, in particular, in terms of strict compliance with norms and rules of waste management, are characteristic not only for the regions of Ukraine, but also for some EU countries.

The specific indicator of waste generation in Ukraine per capita is $9.9 \mathrm{t} /$ year. This makes it possible to compare it with a group of EU countries with the same level of waste generation. This group of countries includes Bulgaria, Finland, Estonia, and Romania. Another sign of significant regional differences between the EU countries is the presence of a strong mining industry with associated waste. These are, in addition to those already mentioned, Austria, Belgium, Germany, and France.

These features (technological backwardness and the predominant share of the mining industry in the economy without a developed structure of associated waste processing) form regional differences in waste management in Ukraine. Their combined impact causes significant regional problems in waste management. This, in particular, is typical for Dnipro, Donetsk, Kropyvnytskyi, and Poltava.
Since Ukraine has proclaimed its European vector of development, the main tasks of implementing European approaches to waste management policy are to get out of the post-Soviet paradigm, i.e., first, the formation of a single regulatory framework in this area, and secondly, the introduction of European technologies and practices of waste management, thirdly, promoting the development of environmental public awareness to ensure public control in this area.

In 2018, almost half (45.0\%) of hazardous waste processed in the EU-27 was disposed of: $37.4 \%$ by recycling or backfilling (equivalent to $69 \mathrm{~kg} /$ person) and $7.6 \%$ by energy recovery, i. e. $14 \mathrm{~kg} /$ person).

The remaining $55.0 \%$ were burned without energy recovery $(5.7 \%$ or $10 \mathrm{~kg} /$ person), buried in landfills, in other words, applied to the ground or by treatment and discharge into water bodies $(33.0 \%$ or $61 \mathrm{~kg} /$ person) or disposed of in another way ( $16.2 \%$ or $30 \mathrm{~kg} /$ person). As can be seen from Fig. 1 (Eurostat. Statistics explained. Waste statistics, 2020), it is the increase in waste recycling that has the largest upward trend compared to 2004 with significant trends to reduce its generation.

For Ukraine, based on the population of 42.2 million according to [5] in 2018, the specific annual values of the total amount of recycled waste is $65 \mathrm{~kg} /$ person, of which the amount of incinerated waste is $0.282 \mathrm{~kg} /$ person, which indicates a significant lag from the level of EU countries.

The experience of the United Kingdom, where the Envirowise program has been implemented to save resources, reduce waste generation and reduce management costs, may be useful for Ukraine. Companies that have benefited from the Envirowise program have saved $£ 297$ million in just one year by reducing the use of raw materials by 84000 tons, the use of water by 17 million cubic meters and reducing waste by 550 thousand tons. Also useful is the use of so-called "waste hierarchy"; focusing not so much on the output of technological processes, but on the input of material flows; changes in thinking, including users. An example of the need to change thinking is that homeowners still want to see their housing supplied with a heating system, although modern technology allows them to build energy-efficient housing that does not require an additional heating system (UK Parliament. Memorandum by Envirowise, 2007)

The second factor is the extensive waste financing system. For example, the European Commission co-finances projects and initiatives to implement EU waste policy. EU regulatory activity in this area is based on significant financial resources. At the same time, funding for the work of the DirectorateGeneral for the Environment (DG ENV) is provided mainly through the LIFE program. LIFE's financial instruments are multifaceted, including loans for waste management projects or equity investments for companies that retain natural capital in a profitable or cost-effective manner. Various funds finance measures to reduce waste generation and restore the environment from accumulated old industrial waste (UK Parliament. Memorandum by Envirowise, 2007). For example, the reduction of marine pollution is funded by the European Maritime and Fisheries Fund. The EU budgetary authority obliges the Budget Office to fund pilot projects for the management of industrial waste, including the Natural Capital Financing Facility (NCFF). A significant part of waste management budgeting is accounted for by grants, in particular by the DirectorateGeneral for the Environment (UK Parliament. Memorandum by Envirowise, 2007).

The third factor is a different (from the Ukrainian one) structure of the economy. Small and medium-sized enterprises make up $99.8 \%$ of private companies in the EU. They provide more than $65 \%$ of jobs in the EU. And the European Commission, realizing, on the one hand, the importance for the economy of these enterprises, on the other, given the combined weight of their impact on the environment, provides them with all possible assistance, including organizational and financial. An example is the grant program of the Executive 


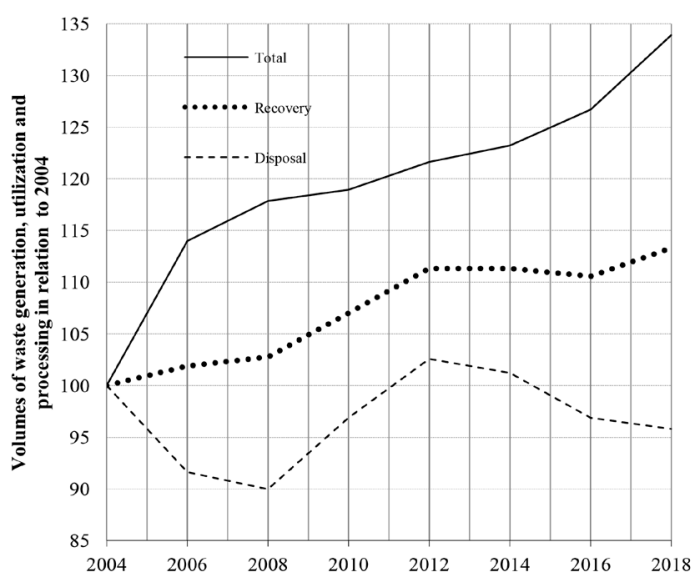

Fig. 1. Volumes of waste generation, utilization and processing in the EU countries in relation to 2004

Agency for Small and Medium Enterprises (UK Parliament. Memorandum by Envirowise, 2007).

Another important factor in EU waste management policy is the use of private companies that specialize in waste disposal. The financial instrument for their promotion is, in particular, procurement contracts - DG ENV purchases services or goods from them on a tender basis.

Another important aspect of the EU policy is the introduction of new and improved waste management technologies. The rating scale of waste management in the EU countries by types of utilization and disposal is given in Fig. 2. From top to bottom, the share of waste disposal decreases and its processing increases. The study identified countries in which the share of the method of backfilling is significant. Backfilling is a recovery operation in which waste is used as a substitute for non-waste materials for land reclamation or other engineering purposes. The analysis revealed that when backfilling is not taken into account, no EU country reaches as much as $70 \%$ of waste recycling. The main reason for this is that construction and demolition waste (CDW) accounts for almost $30 \%$ of all EU waste. CDW is a significant source of secondary raw materials: wood; waste bricks, concrete and stones; drywall; roofs; plastics and metals. CDW has significant potential as a secondary raw material due to the available technology of its processing, but, as can be seen from Fig. 2 there is a group of EU countries that use CDW irrationally. This creates significant regional differences in recycling rates: more than $90 \%$ (the Netherlands, Luxembourg, Italy, Slovenia, Austria and Latvia) and less than $10 \%$ (Finland, Greece and Cyprus). An example of a successful approach to CDW is Flanders, which has achieved a recycling rate of more than $90 \%$, introducing significant taxes on unprocessed waste and strict controls on the disposal of unsorted waste with secondary raw materials to landfills. This allowed forming a market for secondary raw ma-

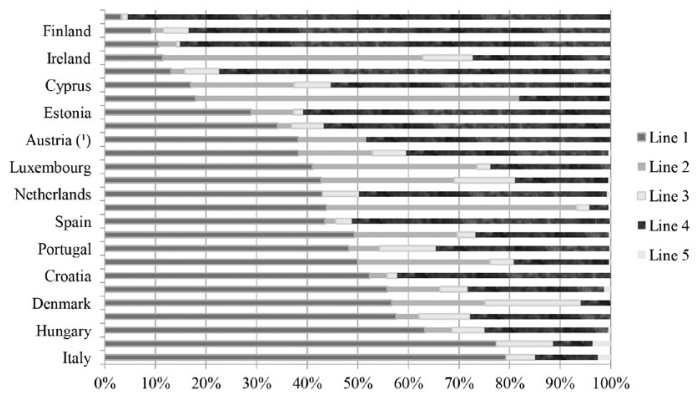

Fig. 2. Waste management in the EU by type of disposal and utilization, 2018:

1 - processing; 2 - backfill; 3 - energy recovery; 4 - burial; 5 combustion without energy recovery terials. An interesting feature is also the introduction of robotic technologies, which reduces the cost of sorting [2]. In particular, Finish ZenRobotics has provided an increase in the yield of useful components from 70 to $90 \%$.

The analysis revealed significant regional differences in EU countries on waste generation by type of economic activity. In this case, the predominant generation of waste for a particular type of economic activity can be offset by a significant level of processing. An example is Sweden having a significant share of mining waste, but also being a leader in waste processing. The country's recycling companies are known to import waste from other EU countries for recycling because their capacity exceeds their own needs.

A structured system with strict legal regulations has been developed in the EU for hazardous waste management. Hazardous waste management is a joint effort of local authorities, business and the public. Hazardous waste is disposed of only by private companies that have a license for this type of activity and work under contracts with those who generate this waste. This prevents the accumulation of hazardous waste.

To study the differences between waste management in Ukraine using the methods of comparative analysis, logical generalization, quantitative and qualitative comparison with the relevant waste management in the EU, in particular, an analysis of annual and total waste accumulated during operation in disposal sites by region and settlement has been conducted.

In 2019, Dnipropetrovsk region $(69.5 \%$ of the total amount of waste), Poltava region (15.8\%), Donetsk region $(5.8 \%)$, Kirovohrad region were the leaders in terms of the volume of waste of I-IV hazard classes, \%). Together, this is $94.6 \%$ of the total amount of 15390609.5 thousand tons. But a completely different situation is with the accumulation of waste I-III hazard classes. The leaders here are Zaporizhzhia region (62.6\% of the total), Sumy region (19.2\%), Luhansk region $(7.0 \%)$, Donetsk region $(6.6 \%)$ while Dnipropetrovsk region has only $1.6 \%$. Together, this is $97.0 \%$ of the total waste of 12232.5 thousand tons.

The analysis revealed that the group of regions has a tendency to reduce the accumulation of industrial waste of I-III hazard classes compared to the volume of waste generation in 2017.

For example, for Luhansk region this reduction was $1.4 \%$. Mykolaiv region became the leader of the decrease in volumes of generation of industrial waste. Unfortunately, this trend is related not so much to the success of environmental activities in these regions, but to the reduction of production at mining enterprises, which make a major contribution to the formation of waste in these regions. First of all, this factor is typical for Luhansk region where the reduction of production is due to military actions.

The increased growth of industrial waste in Sumy region (increase compared to 2017 by $4.35 \%$ ), Donetsk region (increase compared to 2017 by $6.45 \%$ ) confirms the thesis about the insufficient impact of environmental measures on the trend of industrial waste generation in the main regions of industrial waste generation. At the same time, the general trend of accumulation of industrial waste in the country as a whole is relatively stable.

This issue is explained by the fact that a certain increase in the accumulation of industrial waste in some regions is offset by a reduction in this indicator in other regions.

This is illustrated by the analytical information presented, in particular, in Fig. 6, where the volume of generated, utilized and removed waste of I-III hazard classes in specially designated places and facilities is given, and in Fig. 7, where the total amount of waste of I-III hazard classes, accumulated during operation in specially designated places and facilities is shown.

The study indicated a stable trend of steady growth of industrial waste of I-III hazard classes for the period 2015-2021 
by $4.16 \%$ (the ratio of the volume of 2021 to the amount of accumulated waste in 2015).

This trend is the evidence, on the one hand, of the relatively low growth rate of accumulated waste, on the other hand, of the insufficient level of effectiveness of environmental measures and industrial waste management policies in the country.

The method of comparative analysis shows that, in contrast to the EU, the peculiarity of industrial waste generation in some regions of Ukraine is the limited range of industries that give the main increase in waste. For example, for Poltava region it is PJSC "Poltava Mining and Processing Plant", which has accumulated 2402.3 thousand tons of waste from the extraction and dressing of iron ore.

The analysis of Donetsk and Luhansk regions is complicated by the fact that the statistical reports take into account data without temporarily occupied territories. With this in mind, it can be argued that only a few regions (4-5) contribute the main share to the accumulation of the main volumes of industrial waste. Moreover, in each of the problem areas there is a limited number of enterprises whose waste management is inadequate. This should contribute to state and regional waste management policies, but the interests of business owners and the chronic lack of financial resources for industrial waste management still prevail over environmental issues.

Comparison of trends in capital investment in environmental protection in general and waste management indicates their incommensurability (Fig. 3). At the same time, the limited instruments of waste management policy in Ukraine, in contrast to the EU, are due to the lack of the main financial resource for these purposes - funds from regional and state budgets. As can be seen in Fig. 3, the slope ratio of the first trend is 387 times less than the second.

This indicates not only that the item "waste management" is not a priority for investment in relation to other environmental costs, but also the trend of state and regional waste management policy. For a more detailed analysis, changes in the share of investments in waste management in the total capital investment were studied (Fig. 4).

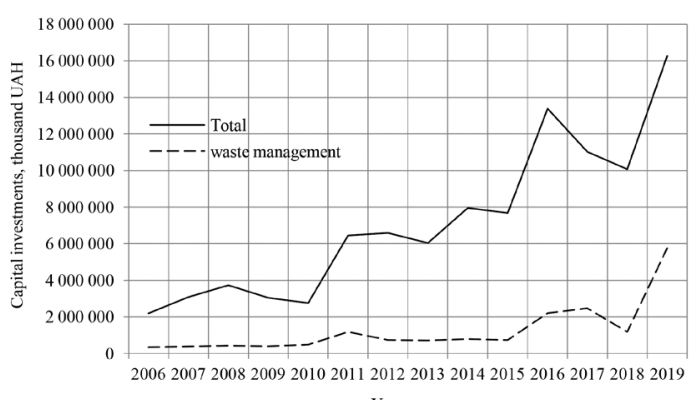

Years

Fig. 3. Capital investments for environmental protection in general and for waste management in actual prices, thousand UAH

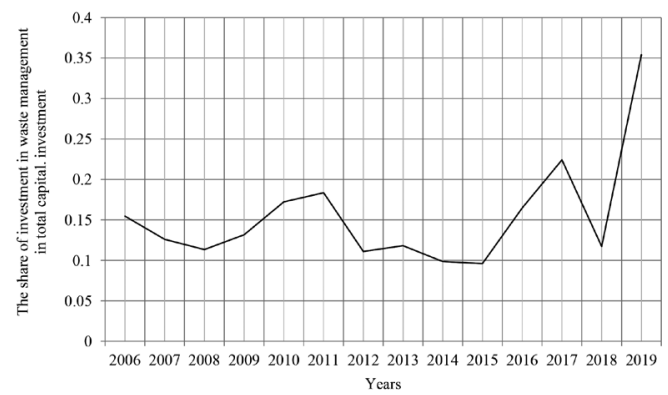

Fig. 4. Share of investments in waste management in the total capital investment:

Row 1 - the ratio of annual capital investment in waste management to the total annual investment in environmental protection
A comparison of 2018 to 2019 shows a threefold increase. But comparing the indicators of 2017 and 2019, we get a much lower growth rate - only $58 \%$.

The use of methods of comparative analysis, quantitative and qualitative comparison of the share of investment in individual industries in total capital investment in environmental protection in Ukraine allowed establishing a faster growth rate of investment for mining, slightly lower for manufacturing and significant (by $46 \%$ according to comparing trends by their slope ratios) lag in the supply of electricity, gas, steam and conditioned air.

This has a significant impact on the formation of regional environmental policy and the peculiarities of this policy of regional settlements, as these industries are differently represented in the regions (as well as in EU countries), to a greater extent in Dnepropetrovsk, Donetsk, Zaporizhzhia, IvanoFrankivsk, Kyiv, Lviv, Mykolaiv regions (Figs. 5-8).

The application of the method of comparative analysis to the total annual costs of environmental protection and annual costs of waste management in previous years and the results of forecasting for the period 2020-2021 (Fig. 5) proves the incompatibility of their trends.

The slope ratio of the first trend is less than the second by $57 \%$. This is a sign of the difference between the priorities of

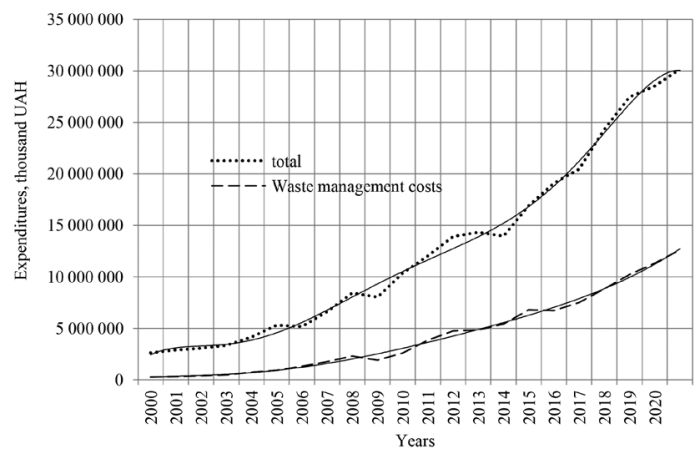

Fig. 5. Total annual running costs of environmental protection and annual costs of waste management

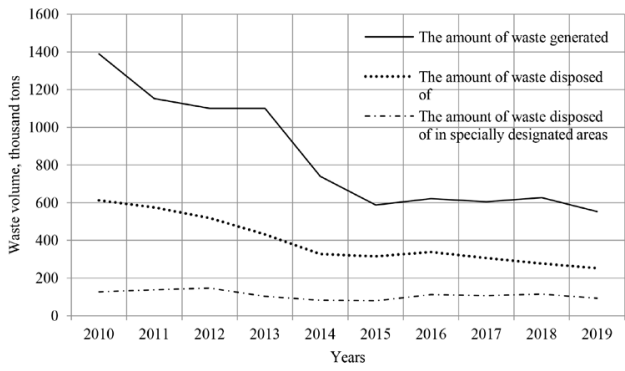

Fig. 6. Volume of generated, utilized and removed waste of IIII hazard classes in specially designated places and facilities, thousand tons

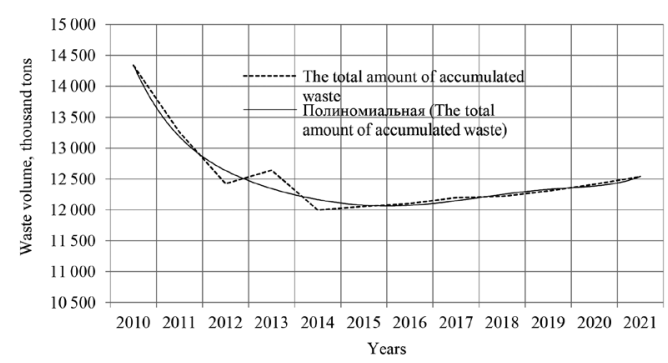

Fig. 7. The total amount of waste of I-III hazard classes, accumulated during operation, in specially designated places and facilities 


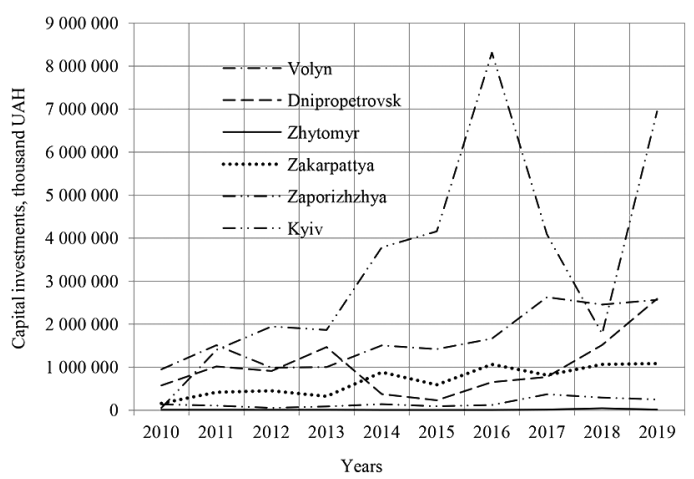

Fig. 8. Volume of capital investments for environmental protection by regions in actual prices, thousand $U A H$

state and regional environmental policy in Ukraine and the $\mathrm{EU}$ and a prerequisite for the growing crisis in waste management for Ukraine.

The analysis of waste management of I-III hazard classes in Ukraine, in contrast to the EU, indicated signs of a growing crisis, which is especially dangerous for settlements near which the accumulation of such waste is concentrated.

The analysis of waste management of I-III hazard classes (Fig. 6) indicates, on the one hand, the reduction of waste generation from year to year, which meets the requirements of the Annex to the Basic Principles of State Environmental Policy according to which it is necessary to halve the percentage of the total number of enterprises using hazardous chemicals, and, on the other hand, contrary to the directive (The Law of Ukraine, Document 697-VIII, 2019), there is a trend of reducing the share of recycled waste (Fig. 6).

Compared to 2015, in 2019 the volume of generation was reduced by $6.1 \%$, the volume of utilization - by $20.6 \%$, the volume of burial - increased by $18.7 \%$. That is, the comparison of the rates of generation, utilization and accumulation of waste shows a significant increasing deterioration of the environmental situation. This is confirmed by the analysis of the forecast of total volumes of accumulated hazardous waste (Fig. 7), with a trend of stable growth of waste of I-III hazard classes in storage sites not only in the past but also in the future. Comparison of 2015 with 2021 gives an increase of $10.4 \%$, which, given the already accumulated volumes, provides significant volumes.

Analysis of the volume of capital investment in environmental protection by region indicates not only their incommensurability, but also fluctuations from year to year. A typical example of this is the indexes of Kyiv. And the apparent tendency to investment increase in actual prices from 2011 to 2019 should be corrected by the fall of the hryvnia to the US dollar 3.7 times during this period. Then, for example, the growth of this indicator for Volyn from 2011 to 2019 by $5.3 \%$ will be replaced by a significant reduction.

The analysis of capital investments in environmental protection by regions indicates that the main volume of invest-

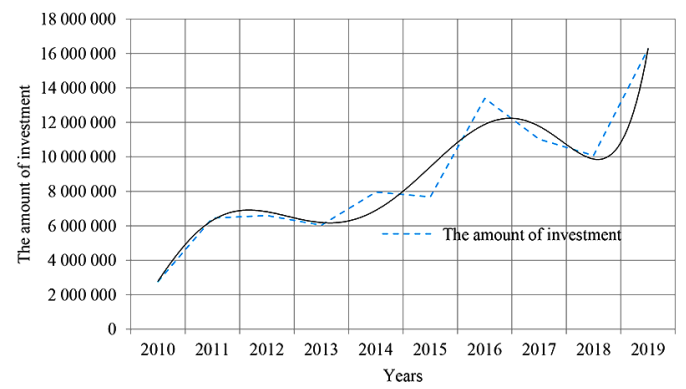

Fig. 9. Volume of capital investments in environmental protection by regions that receive the most, in actual prices, thousand $U A H$ ments falls on Dnipropetrovsk, Donetsk, Zaporizhzhia, Ivano-Frankivsk, Kyiv, Lviv, Mykolaiv, Poltava regions and the city of Kyiv (Fig. 8). In 2019, the share of these regions selected for analysis, the results of which are presented in Fig. 9, was $63.8 \%$ in the total amount of capital investments. That is, the study of the general trend for the selected group of regions is representative.

Conclusions. The study found that despite some similarities in the formation of regional features of waste management policy in Ukraine and the EU, the existing differences in this policy lead to increasing problems in this area for Ukraine.

Significant regional inequalities in Ukraine in terms of accumulation of significant volumes of industrial waste of I-IV hazard classes where the leaders are Dnipropetrovsk, Poltava, Donetsk and Kirovohrad regions (94.6\% of the total) and IIII hazard classes where the leaders are Zaporizhzhia, Sumy, Donetsk and Luhansk regions (together $97 \%$ of the total) and trends in these indicators have been identified. Such a limited number of regions, which mainly accumulate waste, should contribute to the implementation of effective state and regional environmental policy, but differences in approaches in Ukraine and the EU, in particular in the instruments for financing environmental projects, lead to the accumulation of problems. In contrast to the EU, the limitation of financial instruments to budgetary resources alone leads to a reduction in the already insufficient amount of capital investment in waste management.

The analysis of investment in waste management by polluting industries, which are unevenly represented in different regions of Ukraine, revealed outpacing rates of investment in the extractive industry, lesser rates for the processing industry and a significant growing lag in the supply of electricity, gas, steam and conditioned air.

The threatening tendency of growth of the general volumes of accumulation of waste of the I-III hazard classes is revealed. Analysis of capital investments in environmental protection by region indicates that the main volume of investments falls on Dnipropetrovsk, Donetsk, Zaporizhzhia, Ivano-Frankivsk, Kyiv, Lviv, Mykolaiv, Poltava regions and the city of Kyiv, which does not always coincide with the leading regions of waste accumulation and does not correlate with the volume of accumulation.

Unlike the EU, the lack of financial incentives for the introduction of efficient waste management technologies leads to the strengthening of existing and the formation of new threats in the sphere of waste management in Ukraine.

\section{References.}

1. Andreichenko, A., Andreichenko, S., \& Smentyna, N. (2021). Ensuring Biosphere Balance in the Context of Agricultural Waste Management. Philosophy and Cosmology, 26, 46-61. https://doi. org/10.29202/phil-cosm/26/4

2. Pavlova, O. (2018). Politically-Technological Potential of Cultural Practices in Ukrainian Perspective. Ukrainian Policymaker, 2, 20-26. https://doi.org/10.29202/up/2/3.

3. Analytical note on the state of implementation of the first stage of imple mentation of the National Waste Management Strategy in Ukraine until 2030 (2019). Retrieved from http://epl.org.ua/wp-content/uploads/2019/04/analitychna-zapyska-Natsstartegiya.docx.

4. Bondar, O. I. (Ed) (2016). National report on the implementation of national environmental policy. Kherson, FOP Green DS Company Publishing House. Retrieved from http://dea.edu.ua/img/source/ Doc/ecopol.pdf.

5. Krichevsky, S., \& Levchenko, V. (2021). Human Life and Evolution in Biospheres on Earth and Outer Space: Problems and Prospects. Future Human Image, 15, 39-58. Retrieved from http://www.fhijournal. org/15-4/.

6. Bilan, Y., Nitsenko, V., \& Havrysh, V. (2017). Energy aspect of vertical integration in agriculture. Rynek Energii, 5(132), 98-110.

7. Voitsikhovska, A., Kravchenko, O., Melen-Zabramna, O., \& Pankevych, M. (2019). European best waste management practices. Lviv, Manuscript Company Publishing House. Retrieved from http://epl.org. ua/wp-content/uploads/2019/07/Krashchi ES praktuku NET.pdf. 
8. Soroka, L. (2020). Modern Challenges to Establishing Global Law on Sustainable Development of Space Activities. Advanced Space Law, 6, 64-71. https://doi.org/10.29202/asl/6/7.

9. Chukurna, O., Nitsenko, V., Kralia, V., Sahachko, Y., Morkunas, M., \& Volkov, A. (2019). Modelling and Managing the Effect of Transferring the Dynamics of Exchange Rates on Prices of MachineBuilding Enterprises in Ukraine. Polish Journal of Management Studies, 19(1), 117-129. https://doi.org/10.17512/pjms.2019.19.1.09.

10. Ciuła, J., Gaska, K., Siedlarz, D., \& Koval, V. (2019). Management of sewage sludge energy use with the application of bi-functional bioreactor as an element of pure production in industry. E3S Web of Conferences, 123, 01016. https://doi.org/10.1051/e3sconf/201912301016.

11. Cabannes, Y. (2019). The contribution of participatory budgeting to the achievement of the Sustainable Development Goals lessons for policy in Commonwealth countries. Common wealth Journal of Local Governance, 21, 1-19. https://doi.org/10.5130/cjlg.v0i21.6707.

12. Ilić, M., \& Nikolić, M. (2019). Drivers for development of circular economy - A case study of Serbia. Habitat International, 56, 191-200. https://doi.org/10.1016/j.habitatint.2016.06.003.

13. Prieto-Sandoval, V., Jaca, C., \& Ormazabal, M. (2018). Towards a consensus on the circular economy. Journal of Cleaner Production, 179, 605-615. https://doi.org/10.1016/j.jclepro.2017.12.224.

14. Geissdoerfer, M., Savaget, P., Bocken, N., \& Hultink, E. (2017). The Circular Economy - A new sustainability paradigm? Journal of Cleaner Production, 143(1), 757-768. https://doi.org/10.1016/j. jclepro.2017.12.048.

15. Reike, D., Vermeulen, W. J. V., \& Witjes, S. (2018). The circular economy: New or Refurbished as CE 3.0? - Exploring Controversies in the Conceptualization of the Circular Economy through a Focus on History and Resource Value Retention Options. Resources, Conservation and Recycling, 135, 246-264. https://doi.org/10.1016/j.resconrec.2017.08.027.

16. Ghisolfi, V., Chaves, G.D. L. D., Siman, R. R., \& Xavier, L. H. (2017). System dynamics applied to closed loop supply chains of desktops and laptops in Brazil: A perspective for social inclusion of waste pickers. Waste Management, 60, 14-31. https://doi.org/10.1016/j.wasman.2016.

17. Aderoju, O. M., Dias, G.A., \& Gonçalves, A. J. (2018). A GISbased analysis for sanitary landfill sites in Abuja, Nigeria. Environment, Development and Sustainability, 22, 551-574 (2020). https://doi. org/10.1007/s10668-018-0206-z.

18. Bazaluk, O., Havrysh, V., Nitsenko, V., Baležentis, T., Streimikiene, D., \& Tarkhanova, E.A. (2020). Assessment of Green Methanol Production Potential and Related Economic and Environmental Benefits: The Case of China. Energies, 13(12), 3113. https:// doi.org/10.3390/en 13123113 .

19. Bazaluk, O., Havrysh, V., \& Nitsenko, V. (2021). Energy and Environmental Assessment of Straw Production for Power Generation. E3S Web of Conferences, 228, 01010. https://doi.org/10.1051/e3sconf/202122801010.

20. Koval, V., Mikhno, I., Trokhymets, O., Kustrich, L., \& Vdovenko, N. (2020). Modeling the interaction between environment and the economy considering the impact on ecosystem. E3S Web of Conferences, 166, 13002. https://doi.org/10.1051/e3sconf/202016613002.

\section{Державна та регіональна політика поводження із промисловими відходами: досвід СС для України}

\author{
П. С. Покатаєв ${ }^{1}$, І. Б. Гаркавий ${ }^{1}$, В. С. Колтун², \\ Н. В. Шамрай
}

1 - Класичний приватний університет, м. Запоріжжя, Україна, e-mail: Victor30077788@gmail.com

2 - Національна академія державного управління при Президентові України, м. Київ, Україна

3 - Київська міська державна адміністрація, м. Київ, Україна

4 - Національна академія Національної гвардії України, м. Харків, Україна

Мета. Виявити основні тренди, обумовлені розбіжністю політики України та ЄС у формуванні, накопиченні відходів і загрози довкіллю.

Методика. За використання методів контент-аналізу, кількісного та якісного порівняння проаналізована політика $\mathrm{EC}$ щодо управління відходами. Метод логічного узагальнення застосовано для встановлення особливостей фінансування поводження з відходами для галузей і регіонів.

Результати. Виявлені регіональні нерівномірності накопичення промислових відходів, включаючи небезпечні, тренди їх зміни. Встановлені причини регіональних особливостей поводження з відходами у країнах $\mathrm{CC}$ і Україні. Встановлено, що розподіл капітальних інвестицій як в охорону довкілля в цілому, так і в поводження з відходами, не завжди співпадає з областями-лідерами накопичення та не корелюється з обсягами накопичення відходів у регіонах. Встановлено, що, на відміну від ЄС, обмеженість фінансових інструментів поводження з відходами лише бюджетними ресурсами призводить до скорочення обсягів капітальних інвестицій. Порівняння трендів витрат на охорону довкілля й поводження з відходами вказало на їх значну різницю. Аналіз інвестування охорони довкілля за галузями-забруднювачами, що нерівномірно представлені в різних регіонах, виявив значну різницю між ними.

Наукова новизна. Встановлені регіони, що є основними забруднювачами. Виявлена невідповідність трендів обсягів капітальних інвестицій на охорону довкілля й поводження з відходами. Встановлено, що список областейлідерів за капітальними інвестиціями в охорону довкілля не корелює зі списком областей-лідерів накопичення відходів. Вказано, що нерівномірності інвестування створюють ризики збільшення темпів накопичення відходів, зокрема, небезпечних. Проведено прогнозування покажчиків поводження з відходами наступних періодів.

Практична значимість. Встановлені ризики збільшення темпів накопичення відходів, у першу чергу небезпечних, як у цілому по Україні, так і за окремими регіонами, нерівномірності за окремими областями в обсягах капітальних інвестицій у захист довкілля, що дозволить сформувати ефективну політику поводження з відходами. Виявлення спільних рис і відмінностей у поводженні з відходами в $\mathrm{EC} \mathrm{і} \mathrm{Україні} \mathrm{дозволить} \mathrm{запровадити} \mathrm{ефек-}$ тивні інструменти охорони довкілля, зменшити ризики в управлінні промисловими відходами.

Ключові слова: промислові відходи, державна політика, населені пункти, регіони

Recommended for publication by D. Bikulov, Doctor of Sciences in Public Administration. The manuscript was submitted 14.12.20. 